\title{
LIVING AS IF GOD EXISTS: \\ LOOKING FOR A COMMON GROUND \\ IN TIMES OF RADICAL PLURALISM
}

\section{PETER JONKERS}

Tilburg University

\begin{abstract}
This paper offers some comments on some metaphysical and epistemological claims of (critical) theological realism from the perspective of continental philosophy of religion, thereby taking the work of Soskice and Hick as paradigmatic for this kind of philosophical theology. The first comment regards the fact that theological realism considers religious and theological propositions as ways to depict or represent reality, and hence aims to bring them as much as possible in line with scientific ones. Some contemporary French philosophers (Ricoeur, Lévinas, and Marion) criticize such a representing, depicting knowledge of God, because it encapsulates the divine reality in mundane, specifically scientific categories. Eventually, theological realism runs the risk of annihilating God's radical transcendence and reducing religion to an alternative scientific theory. The second comment tries to explore whether one can affirm God's reality from a practical perspective, as a postulate of reason, and whether such an approach could serve as a common ground for religious and secular (practical) ways of life in times of radical pluralism. This comment begins by investigating the regulative character of Kant's idea of God as the highest idea of reason, which not only orientates our theoretical enquiries, but also our moral actions. Although this idea is only a heuristic fiction for theoretical reason, God's existence has to be affirmed on practical grounds, as a symbolic reality that gives orientation to people's lives.
\end{abstract}

\section{INTRODUCTION}

The debate between the proponents of theological realism and those of theological anti-realism has been almost exclusively the affair of analytic philosophy of religion. Unfortunately, contemporary continental 
philosophy of religion has hardly paid attention to this debate, and hence has failed to enter into a fruitful dialogue with analytic philosophy of religion on this issue. In my view, one of the reasons for this neglect is that the core of the debate about (theological) (anti)realism has largely been perceived as a metaphysical one. Because contemporary continental philosophy predominantly concentrates on a deconstruction of metaphysics, it feels entitled to leave this debate aside. Another reason is that not only most continental, but also some analytic philosophers of religion, such as D.Z. Phillips, consider religion as primarily as giving orientation to life, rather than as a set of theoretical propositions about natural and supernatural states of affairs, which seems to be the focus of most proponents of theological (anti)realism. ${ }^{1}$ Finally, continental philosophy is hardly interested in the kind of epistemological issues that analytic philosophy of religion is dealing with. If continental philosophy pays any attention at all to these kinds of questions, it does so in order to highlight the (problematic) consequences of religious truth claims in a pluralistic society.

In this paper I want to offer a modest contribution to a dialogue between analytic and continental philosophy of religion, by commenting on some underlying assumptions of theological realism from the perspective of continental philosophy of religion. The first comment regards the fact that theological realism considers religious and theological propositions as ways to depict reality, and hence aims to bring them as much as possible in line with scientific ones. More specifically, I will examine if an interpretation of God's reality on the basis of this metaphysical paradigm is tenable religiously. In this section I take Janet Soskice's work on theological realism as my point of departure. The second comment tries to explore whether a different kind of theological realism could be an option. In particular, I want to examine what happens to God's reality if one starts from the life-orienting dimension of religion rather than on focusing on His existence from a theoretical perspective. Moreover, I want to investigate whether such an approach could serve as a common ground in times of radical pluralism. In this section, I take John Hick's work as my point of departure.

${ }^{1}$ In support of this distinction between a theoretical and a practical approach of religion, see Niek Brunsveld, The Many Faces of Religious Truth: Developing Hilary Putnam's Pragmatic Pluralism into an Alternative for Religious Realism and Antirealism (Utrecht: Utrecht University, 2012), pp. 11f. Brunsveld distinguishes between the supernatural, the natural, and the life-orienting aspects of religion. 


\section{THE PROBLEM OF DEPICTING GOD'S REALITY}

A fundamental epistemological assumption of theological realism is that religious or theological language is capable of depicting the divine reality, and hence, of offering a representing knowledge of this reality. Philosophical realism in general can be defined as holding that the historicity of linguistic understanding and the contextuality of meaning do not at all exclude that there can be criteria of meaning, truth and rationality that surpass contextuality and are related to reality. [...] Realist theories want to keep the claim on a possible objectivity of the human activity of meaning giving and proposition making, which goes beyond purely intersubjective or parochial convictions.'2 As Janet Soskice has pointed out, a common claim of all kinds of philosophical realism is that our language somehow refers to reality, more specifically that science depicts reality by making use of models and metaphors. ${ }^{3}$ Whereas in naïve realism, 'models are viewed as providing a description of how things are in themselves, and science is seen as a process of making immediate the hitherto invisible structures of the world', ${ }^{4}$ critical realism considers these models 'not as logical ciphers but as terms which putatively refer to possible real entities, relations, and states of affairs. ${ }^{5}$ In sum, critical realism does not see the models and metaphors, used by scientific explanation, as heuristic fictions; instead, it regards scientific explanation as reality depicting. This does not mean that critical realism claims that science mirrors the world; rather it sees scientific terms 'as representing reality without claiming to be representationally privileged.' 6 This shows that Soskice makes a distinction between the reality depicting or referential intention of all scientific explanation and the figurative character of the actual descriptions that scientific models and metaphors provide of reality, implying that none of them has a privilege in representing reality.

Given the fact that metaphors not only play an important role in scientific theories, but are even more predominant in the domain of

${ }^{2}$ Hans-Peter Großhans, Theologischer Realismus: Ein sprachphilosophischer Beitrag zu einer theologischen Sprachlehre (Tübingen: Mohr, 1996), p. 6.

${ }^{3}$ Janet Martin Soskice, Metaphor and Religious Language (Oxford: Clarendon Press, 1985), pp. 118 and 136.

${ }^{4}$ Janet Martin Soskice, Metaphor and Religious Language, p. 118.

${ }^{5}$ Janet Martin Soskice, Metaphor and Religious Language, p. 120. See Hans-Peter Großhans, Theologischer Realismus, pp. 12f.

${ }^{6}$ Janet Martin Soskice, Metaphor and Religious Language, p. 132. 
religion and theology, Soskice applies the above distinction to religion and theology: they claim, just like science, to depict reality without having the pretension of giving a definitive and adequate description of the divine reality 'as it is'. She considers Anselm's famous formula in the Proslogion, 'God is that than which nothing greater can be conceived', as an excellent example of designating what a God must be without describing God. ${ }^{7}$ Analogous to philosophical realism, theological realism can metaphysically speaking be defined as 'the view that there is a transcendent divine reality independent at least in part of human thought, action and attitudes. ${ }^{8}$ On an epistemological level, theological realism holds that our religious and theological language has the intention and is in principle able to depict this reality. Hence, religious language should not be taken only as expressing an emotive meaning, but also as having a reference to a human-independent reality, that can in principle be represented by human language. In sum, according to critical theological realism, the theist can reasonably take his talk of God, bound as it is within a wheel of images, as being reality depicting, while at the same time acknowledging its inadequacy as description.'

In my view, Soskice's distinction between referring to God and defining or describing Him presents a major contribution to theological realism, in particular because it does justice to the insights of negative theology when we speak about God's reality: 'In our stammering after a transcendent God we must speak, for the most part, metaphorically or not at all. ${ }^{10}$ However, from the perspective of contemporary continental philosophy, a major problem of Soskice's approach is that she narrows down our religious and theological referring to God's reality to depicting or representing him. This enables her to link the kind of explanation of the world that religion and theology offer closely to a scientific explanation. But this goes at a considerable cost, namely that of turning religion and theology into the same kind of objectifying language and knowledge as science. The fact that theological realism aims to represent God raises the question whether this does not lead to encapsulating

${ }^{7}$ Janet Martin Soskice, Metaphor and Religious Language, p. 138.

${ }^{8}$ Hans-Peter Großhans, Theologischer Realismus, p. 1. In a similar vein, John Hick defines religious realism as 'the view that the objects of religious belief exist independently of what we take to be our human experience of them'. See: John Hick, An Interpretation of Religion: Human Responses to the Transcendent (Basingstoke: MacMillan, 1989), p. 172.

${ }^{9}$ Janet Martin Soskice, Metaphor and Religious Language, p. 141.

${ }^{10}$ Janet Martin Soskice, Metaphor and Religious Language, p. 140. 
him in a kind of objectifying knowledge that inevitably annihilates his divinity. In particular, Soskice does not seem to realize that the way in which e.g. physics uses the metaphor of the Big Bang in order to describe the origin of the universe differs completely from the metaphorical way in which Christians call God the creator of the world. I fully agree with her that metaphors play an essential role both in science and in religion, but there is a gulf that separates scientific metaphors from religious ones. The above example shows that not only is the relation between religious language and the reality it refers to a metaphorical one, but also the relation between religious and scientific language. Whereas Soskice deserves full credit for having clarified the former, she fails to give account of the latter.

\subsection{The critique of onto-theology}

As is common knowledge, the problems of a representing knowledge of God's reality and of putting religion and theology on the sameline as science were first developed by Heidegger in the context of his deconstruction of metaphysics as ontotheology. It has had such an influence among continental philosophers that a whole generation considered any philosophical reflection on God's existence as contradictory. As I will show in the next subsection, three contemporary French philosophers, Paul Ricoeur, Emmanuel Lévinas, and Jean-Luc Marion, have taken Heidegger's critique to heart, but without considering it as the final judgment against thinking about God's reality philosophically. On the contrary, Heidegger has inspired them to develop alternative approaches, which present relevant alternatives to theological realism's representing knowledge of God. ${ }^{11}$

For Heidegger, the ontotheological nature of metaphysics has come to the fore since modernity, in particular from the moment that Being was reduced to an object of representing reasoning, human subjectivity was posited as the unique point of reference for all truth and value, and truth was defined in terms of objective certainty. This dramatic change in the history of Western culture has resulted in the rise of modern science, but it has also had an enormous impact on most philosophical approaches of God's existence. A closer look at modern philosophy and science shows

${ }^{11}$ I developed this issue in more detail in Peter Jonkers, 'God in France: Heidegger's Legacy', in Peter Jonkers, Ruud Welten (eds.), God in France: Eight Contemporary French Thinkers on God (Leuven: Peeters, 2005), pp. 1-42. 
that the two are closely linked together: science accepts the philosophical idea of God as the ultimate foundation of nature, and philosophy accepts the kind of foundational knowledge that science offers as its paradigm. A clear example of this is link the concept of (sufficient) ground: Being is understood as ground, while thinking gathers itself towards Being as its ground in the manner of giving ground and accounting for the ground. ${ }^{12}$ This ground is the ultimate principle, on the basis of which science and philosophy can represent the whole of reality as something radically coherent and transparent. From a philosophical perspective, only God qualifies for being this absolute ground and, consequently, modern philosophy attributes a central position to Him. Concretely, Heidegger thinks of Descartes' idea of the infinite, Leibniz's principle of sufficient ground, Spinoza's absolute substance, and Hegel's absolute idea. Theological realism could be added to this list, because it is governed by the same ideal of foundational and representing knowledge as modern science.

In the work of Ricoeur, the theme of the deconstruction of ontotheology plays a major role in his struggle with the tradition of reflective philosophy. Its discourse is characterized by universality, univocity, and unity and, as such, it is opposed to the plurality, equivocity, and particularity of the myths. With regard to the thinking of God, reflective philosophy proves that it is unable to think the essence of what faith is all about, the Wholly Other who addresses and questions us. This kind of philosophy is situated on the level of immanence and, therefore, it cannot say anything about vertical transcendence. According to Ricoeur, the ideal of foundationalism, on which reflective philosophy ultimately rests, is a manifestation of its hubris. Instead, philosophy should start from the plurality of individual myths and symbols, and reveal the universal and rational structure which is hidden in all religions. The consequence of this approach is not only an enlargement, but also a qualitative change of reflective consciousness. More specifically, it puts autonomous thinking and its ideal of complete reflexivity, transparency, and foundationalism under pressure. Ricoeur's argument ends in a rehabilitation of non-speculative language, a way of thinking without the totalizing and foundational pretensions of traditional metaphysics. ${ }^{13}$

\footnotetext{
${ }^{12}$ Martin Heidegger, 'Die onto-theo-logische Verfassung der Metaphysik', in Martin Heidegger, Identität und Differenz (Pfüllingen: Neske, 1957), pp. 31-67 (p. 48).

${ }^{13}$ For an excellent analysis of this aspect of Ricoeur's work, see: Theo de Boer, 'Paul Ricoeur: Thinking the Bible', in Peter Jonkers, Ruud Welten (eds.), God in France, pp. 43-67.
} 
The critique of a thinking that aims at depicting and representing reality is also the point of departure in Lévinas's philosophical project. It aims at thinking of a God who does not coincide with the (supreme) being, but is precisely otherwise than Being. In one way or another ontotheology annihilates God's incomprehensible infinity by fitting him into a totalizing system. As a consequence, God's transcendence is overpowered and the infinite difference between man and God is ignored. By conceiving God within the network of Being, ontotheology also creates the impression of being able to thematize God and reduce Him to an object of re-presenting thinking. ${ }^{14}$ Moreover, the subject appears in this context as the unique starting point of all initiative in the world; as such, the subject is convinced that it can never be disturbed, thrown off its balance, or displaced by the intrusion of the infinite. Hence, 'it is no coincidence that the history of western philosophy has resulted in an annihilation of transcendence. ${ }^{15}$ Lévinas thereby explicitly includes rational theology, and hence theological realism, and this in spite of its attempts to do justice to the idea of transcendence by qualifying God's existence with adverbs such as 'eminently' or 'par excellence'. In sum, Lévinas radically rejects all thinking that tries to represent or depict him, and this includes theological realism. Instead, the core of his philosophical project is 'to hear a God not contaminated by Being. ${ }^{16}$

Marion's critique of ontotheology is influenced by that of Heidegger and Lévinas, as already becomes apparent from the startling title of his book God Without Being (Dieu sans lêtre). ${ }^{17} \mathrm{He}$ uses the twin concepts idol and icon to clarify and balance this issue. Idol refers to a human experience of the holy; it is a representation of the holy as seen only from a human point of view. A representation fixates, and the idol is precisely the point where the movement of fluid thinking stops and fixates itself. As far as philosophical theology is concerned, this attitude refers to a way of thinking about God in terms of representing and depicting his reality. As a representation, God is no longer infinite, but is being fixated within the boundaries of the human capacity of representing, and more specifically within those of the correspondence theory. Therefore, in order to avoid

\footnotetext{
${ }^{14}$ Emmanuel Lévinas, De Dieu qui vient à l’idée (Paris: Vrin, 1986), p. 100.

${ }^{15}$ Emmanuel Lévinas, De Dieu qui vient à l’idée, p. 95.

${ }^{16}$ Emmanuel Lévinas, Autrement quêtre ou au-delà de l'essence (Dordrecht: Kluwer, 1978), p. X.

${ }^{17}$ Jean-Luc Marion, Dieu sans lêtre (Paris: Presses Universitaires de France, 1991).
} 
conceptual idolatry one has to think about God outside the purview of metaphysics, and, in particular, outside that of theological realism.

\subsection{Thinking of God as radically transcendent}

It seems clear to me that these comments from the perspective of contemporary continental, in particular French philosophy are very relevant for the debate about theological realism. Ricoeur's critique that natural theology fails to take into account the plurality and particularity of the Christian narrative about God's nature and existence does not turn him into an advocate of the anti-realist position. It rather shows him as someone who has taken Pascal's adage of the rift between the God of the philosophers and the God of Abraham, Isaac and Jacob to heart and has introduced it in the current debate. Through his project of a non-speculative philosophy of religion, Ricoeur tries, on the basis of a hermeneutical analysis of the meaning of the Christian narrative, to discover its universal significance. In this respect, his position comes close to that of internal realism, which, just like Ricoeur, takes the plurality of religious languages as its point of departure, and situates the ontological claims of theological realism within these languages, thereby rejecting the rationalistic foundationalism that characterizes theological realism. ${ }^{18}$ However, an important difference between these two positions is that internal realism leads to the conclusion that the affirmation of God's reality only makes sense within Christian dogmatics, ${ }^{19}$ whereas Ricoeur's hermeneutic approach tries to move beyond the confines of the various religions, which enables him to affirm God's reality on a general, philosophical level.

Lévinas's and Marion's critique of the key concept of theological realism, namely representation or depiction leads them to affirm God as the radical Other, who disrupts all thinking in terms of correspondence and analogy. Lévinas wants to conceive a new, absolute notion of sense which cannot but lie radically at the other side of Being and which we can only trace through ethics as the unconditional appeal of the radically Other to me. With regard to the overcoming of ontotheology, Lévinas fundamentally differs from Heidegger: if philosophy takes God for Being, this inevitably implies that Being becomes the ultimate source of sense.

${ }^{18}$ Hans-Peter Großhans, Theologischer Realismus, pp. $266 f$.

${ }^{19}$ Hans-Peter Großhans, Theologischer Realismus, p. 267. 
This shuts the door to a radically transcendent sense, that is to say, a sense intruding into earthly Being from outside or above, a sense that does not find its origin in the order of 'sameness' but in the incommensurable Other. ${ }^{20}$ Lévinas's thinking aims at showing that an authentic sensegiving thinking, i.e., thinking that looks for a primordial, absolute sense, necessarily implies the explosion or the subversion of Being, since Being itself and the sense of Being only manifest themselves as a contingent history of beings and a heterogeneous multiplicity of senses.

Lévinas's notion 'God as otherwise than being' and, even more radically, Marion's provocative expression 'God without being' are not at all intended to query, let alone to negate the reality of God's existence, and hence are anything but a plea for theological anti-realism. Instead, they are the upshot of their phenomenological investigation of the way in which God 'comes to mind'. This implies a total passivity from the part of the subject, which can be compared to a trauma, inflicted by the idea of the infinite. ${ }^{21}$ Although stemming from a different philosophical tradition, these remarks can only be interpreted as a fundamental critique of theological realism's approach of examining how the human mind can represent or depict God's reality. Phrased positively, these notions are meant to make us sensitive of the excessiveness of God's existence, radically exceeding the boundaries of (earthly) being.

\section{GOD AS A POSTULATE OF REASON}

My second comment on theological realism relates to the title of this paper, 'Living as if God exists'. At first sight, this title seems to cast an agnostic doubt on theological realism. Indeed, it leaves the metaphysical question about the ontological status of a transcendent divine reality as well as the epistemological question whether humans can affirm God's existence on objective grounds open. But, as I will show below in more detail, the expression 'living as if God exists' also encourages people to accept God's existence not so much on objective, but on practical grounds. Moreover, by encouraging all people to live as if God exists, irrespective of whether they are (Christian) believers or not, this expression aims to offer a transcendent common ground for our life-practices in times of radical pluralism.

${ }^{20}$ Emmanuel Lévinas, Dieu, la mort et le temps (Paris: Grasset, 1993), p. 141.

${ }^{21}$ Emmanuel Lévinas, De Dieu qui vient à l'idée, p. 106. 
In the history of philosophy, this position goes back to Kant, more specifically to his approach of God as a regulative idea of theoretical reason and as a postulate of practical reason. For Kant, distinguishing between a constitutive and a regulative employment of this idea is essential for avoiding dialectic semblance. A constitutive employment of the idea of God is erroneous, because it takes God as an object of theoretical knowledge, thus putting Him on a par with the objects of possible sensory experience. ${ }^{22}$ But a regulative use of this idea is indispensible in order to orientate our theoretical thinking towards the greatest possible unity and opens up the way for postulating God's existence on a practical level. I will examine if and how this distinction and its implications on the level of practical philosophy shed a new light on theological realism.

As a sort of captatio benevolentiae for my approach, I want to note that one of the proponents of critical theological realism, John Hick, also makes use of Kant's philosophy in his investigation into the sensibility of affirming God's existence in a situation of religious pluralism. According to Hick, all world religions are valid renderings of the Ultimate Reality. His approach can be qualified as a realist one, because, ultimately, reality confers truth on religious propositions. Basic to Hick's critical theological realism is an interpretation of Kant's distinction between the phenomenal and the noumenal order, between reality as it appears to us and reality as it is in itself (the Real), and the contention that we always experience reality mediated through our preconceptions. ${ }^{23}$ Critical theological realism admits that we are unable to experience or know the Real, but we do have good reasons to affirm its existence, because it appears to us through our concepts, language etc. In other words, critical theological realism rests on the conviction that humans give a cognitive, conceptually mediated and hence culturally situated response to a transcendent reality. We can never experience or know the Real as such, but it cannot be qualified as a purely imaginative projection either. Instead, 'the noumenal Real is experienced and thought by different religious traditions, as the range of gods and absolutes which the phenomenology of religion reports. And these divine personae and

${ }^{22}$ Immanuel Kant, 'Kritik der reinen Vernunft', in Immanuel Kant, Werke in zehn Bänden, Herausgegeben von Wilhelm Weischedel, Band 4: Kritik der reinen Vernunft: Zweiter Teil (Darmstadt: Wissenschaftliche Buchgesellschaft, 1968), pp. B 670-680. All references to Kant's Critique of Pure Reason are taken from the second edition (=B) of 1787.

${ }^{23}$ John Hick, An Interpretation of Religion, p. 241. 
metaphysical impersonae [...] are not illusory but are empirically, that is experientially, real as authentic manifestations of the Real. ${ }^{24}$ In partial agreement, but also partial disagreement with Kant, Hick says that the Real an sich is postulated by us as a pre-supposition, not of the moral life, as it is for Kant, but of religious experience and the religious life. So, humans experience the Real, but only through their categorical schemes, thanks to which the Real becomes a meaningful phenomenal experience, to which they can respond in a cognitive way. The only thing we can say about the Real is that it is the reality whose influence produces, in collaboration with the human mind, the phenomenal world of our (religious) experience and the linguistic interpretations of it. Another important difference with Kant's philosophy is that, whereas the Kantian categories are universal and invariable because of their strictly formal nature, Hick's religious categorical schemes are culture-relative, thus being responsible for the wide variety of existing religions. ${ }^{25}$

Another recent example of someone who re-employs Kant's philosophy in a similar way as Hick is no one less than Joseph Ratzinger. It has to be noted first of all that Ratzinger is very critical of Hick's above-mentioned distinction between the phenomenal and the noumenal as a means to save theological realism in a situation of religious pluralism; he disqualifies this attempt as plainly relativistic, because it allows the Absolute only to exist in the form of historically and culturally situated models, whereas the Absolute as such cannot exist in history. ${ }^{26}$ But notwithstanding his critique of the relativistic (at least, in his view) ${ }^{27}$ conclusions Hick

${ }^{24}$ John Hick, An Interpretation of Religion, p. 242.

${ }^{25}$ John Hick, An Interpretation of Religion, pp. $243 \mathrm{f}$.

${ }^{26}$ Joseph Ratzinger, Truth and Tolerance: Christian Belief and World Religions (San Francisco: Ignatius Press, 2004), pp. 120f. The chapter of this book in which he discusses Hick's views iwas presented as a paper on a conference in Mexico in 1996. See Joseph Ratzinger, Truth and Tolerance, p. 113.

${ }^{27}$ Ratzinger considers relativism (together with the predominance of scientific reason, which is fixated in its opposition to faith) as the most important threat of our times. Unfortunately, he is so much preoccupied by this problem that he fails to appreciate the urgent need of a serious investigation into the problem of (religious) pluralism, and does not seem to see that pluralism cannot be identified with relativism just like that. This prevents him, in my view, from an unbiased examination of Hick's ideas on this issue (see Joseph Ratzinger, Truth and Tolerance, pp. 119-122). For Hick's reaction, in which he points to the unfairness of Ratzinger's critique see: John Hick, Dialogues in the Philosophy of Religion (Basingstoke: Palgrave MacMillan, 2010), pp. 157-160. However, in his later work (his critique of Hick's views on religious pluralism stems from 1996), Ratzinger seems to have taken a somewhat more open position with regard to (religious) 
draws from Kant's theoretical philosophy, Ratzinger appreciates Kant's practical philosophy much more. In his book Christianity and the Crisis of Cultures, Ratzinger boldly suggests that a secular person, 'who does not succeed in finding the path to accepting the existence of God ought nevertheless try to live and to direct his life veluti si Deus daretur, as if God did indeed exist.'. ${ }^{28}$ The reason for Ratzinger to make such an exhortation, thereby referring to Kant's postulates of practical reason and Pascal's wager, is that it enables him to solve the problem of the ultimate foundation of moral normativity in contemporary, pluralist society. The idea of God refers to a dimension of reality and in particular of human life that is more fundamental than the differences in moral convictions between religious and secular people and thus precedes moral consensus building. In Ratzinger's view, the exhortation to live as if God indeed exists refers to the idea that in all human beings' ways of life there is a common ultimate goal, which transcends the here and now. He defines it as the logos that inheres the world, thus showing that this goal is not the result of political consensus building, but reversely that this consensus is oriented by this goal. This serves for Ratzinger as a regulative idea, whose reality has to be postulated in order to serve as a point of orientation for a true consensus between believing and secular people. But precisely because it is a regulative idea, it is impossible for any religion or secular philosophy of life to claim the possession of it; hence the 'as if'. 29

\subsection{God as a regulative idea of reason}

My critique of the objective version of theological realism, offered by Soskice and others, points to the need of an alternative approach to God's reality. The above references to Hick and Ratzinger indicate that

pluralism. See e.g. Joseph Ratzinger, 'That Which Holds the World Together: The PrePolitical Moral Foundations of a Free State', in Jürgen Habermas and Joseph Ratzinger, The Dialectics of Secularization: On Reason and Religion (San Francisco: Ignatius, 2006), pp. 53-80 (p.79).

${ }^{28}$ Joseph Ratzinger, Christianity and the Crisis of Cultures (San Francisco: Ignatius Press), 2006, p. 51.

${ }^{29}$ For a more extensive discussion of Ratzinger's position on this issue see Peter Jonkers, 'A Purifying Force for Reason? Pope Benedict on the Role of Christianity in Advanced Modernity', in Staf Hellemans and Joseph Wissink (eds.), Towards a New Catholic Church in Advanced Modernity: Transformations, Visions, Tensions (Tilburg Theological Studies 5) (Münster: Lit, 2012), pp. 79-102. 
this kind of alternative I suggest is of a practical or life orienting nature. The shift that I suggest can be summarized by Kant's famous quote: 'I had to supersede knowledge in order to make room for faith. ${ }^{30}$ Contrary to some interpretations, this quote is anything but supporting the popular dichotomy between an unfaithful reason and an unreasonable faith. It rather shows that philosophy should, after having recognized that a kind of scientific knowledge that aims at representing or depicting the divine reality does not lead us to an understanding of God's reality. Instead, we should approximate him as the object of a reasonable faith, i.e. a faith that is not based on a particular religious revelation, but on universal reason, and hence has to be studied philosophically. Furthermore, this faith does not affirm God's existence on objective, but rather on subjective grounds, as a regulative idea. Finally, God's reality is a symbolic one, which links him to the cultural world instead of the natural one. In particular, God appears for Kant as the ultimate point of orientation of our lives. In this and the next section, I will explore Kant's complex insight further, focusing on its relevance for theological realism.

The practical approach that I propose and try to develop in this section is not intended to disqualify a theoretical investigation into the nature and characteristics of God's reality. On the contrary, the history of philosophical theology shows that it makes perfect sense to examine theoretically how to understand the articles of faith, e.g. that God is the creator of heaven and earth, that $\mathrm{He}$ is related to the world in a unique way, that $\mathrm{He}$ is a spiritual being, etc. But, in my view, these vital questions of theological realism only become relevant once one has accepted to put one's life in the sign of the risen Lord; that is, from a religious point of view. In other words, theological realism is unable to provide a common ground on the basis of which one can discuss what it means to believe in God. To my mind, a practical approach, which starts from a philosophical investigation into what it means to live as if God exists, is better suited to discuss religious issues in a pluralistic society, because it can be brought into dialogue with other, secular ways of life.

Let us start with exploring the Kantian background of Hick's distinction between the phenomenal and the noumenal and his postulating of the Real an sich as well as Ratzinger's suggestion to a secular person to live as if God indeed exists. For Kant, the idea of God, which belongs to the noumenal sphere, has an 'excellent, and indeed indispensably necessary

${ }^{30}$ Immanuel Kant, 'Kritik der reinen Vernunft', p. B XXX. 
regulative employment. ${ }^{31}$ The function of this idea is that of 'directing the understanding towards a certain goal upon which the routes marked out by all its rules converge, as upon their point of intersection. ${ }^{32}$ The aim of reason is to connect the plurality, which characterizes the body of our knowledge, in conformity with a single, unifying principle, in order to turn this contingent aggregate of knowledge into a systematic whole. This unity of reason does not result from an abstraction of the plurality of our insights, but this plurality reversely presupposes a preceding idea of systematic wholeness, on the basis of which the place of these plural insights in the whole and their mutual relations can be determined. This idea not only orientates us in all our enquiries of nature, but also - as the highest good - in our moral actions. ${ }^{33}$ As we shall see below, it is especially the moral or practical aspect of this orientating idea that is relevant in the context of this paper. On the level of theoretical reason, it is obvious that God cannot be an object of our actual knowledge, but can only be thought as an idea that contains no contradictions. Therefore, theoretical reason can only admit this idea in a problematic way. The term 'problematic' has a very specific meaning in this context: it does not mean that it makes no sense to think about God, but rather that the idea of God is assigned to us as a task for philosophical reflection, with the intention of bringing 'unity into the body of our detailed knowledge, and thereby to approximate the rule of universality. ${ }^{34}$

What seems to me very relevant in Kant's ideas on this issue is first of all the idea that a philosophical reflection on God, including theological realism, should not focus on objective propositions about God's reality, but show that accepting the reality of God is necessary on subjective grounds. The term 'subjective' does not mean that such a reflection is inevitably biased in a religious way, nor that it is nothing but the expression of a private whim, but refers to a need of practical reason to make the highest good to the object of my will. ${ }^{35}$ In other words, the idea

${ }^{31}$ Immanuel Kant, 'Kritik der reinen Vernunft', p. B 672.

${ }^{32}$ Immanuel Kant, 'Kritik der reinen Vernunft', p. B 672.

${ }^{33}$ See: Immanuel Kant, 'Kritik der praktischen Vernunft', in Immanuel Kant, Werke in zehn Bänden, Herausgegeben von Wilhelm Weischedel, Band 6: Schriften zur Ethik und Religionsphilosophie, p. 256, and Immanuel Kant, 'Was heißt: sich im Denken orientieren?', in Immanuel Kant, Werke in zehn Bänden, Herausgegeben von Wilhelm Weischedel, Band 5: Schriften zur Metaphysik und Logik, pp. 271-274.

${ }^{34}$ Immanuel Kant, 'Kritik der reinen Vernunft', p. B 675; see also pp. B 691 and B 697.

${ }^{35}$ Immanuel Kant, 'Kritik der praktischen Vernunft', pp. 256, 276. 
of God is necessary for a human's never ending task to give meaning to the world in which he lives. So the suggestion to think of God as a regulative idea of reason is meant to move philosophical thinking away from all kinds of theoretical considerations about God's nature and attributes, and direct it towards a reflection on the idea of God as an indispensible life-orienting principle.

Although Hick builds on Kant's conception of God as noumenal, he does not follow Kant in his switch from an objective, theoretical approach of God to a subjective, practical one. The consequence of this is that Hick, just like Soskice, ends up with a rather objectivistic approach of God (or of the 'Real', as he calls it), which fails to do justice to the committed, practical way in which all people, regardless whether they are Christian or not, orient themselves in their lives to God. For Hick, 'the Real is experienced by human beings [...] in a manner analogous to that in which [...] we experience the world: namely by informational input from external reality being interpreted by the mind in terms of its own categorical scheme and thus coming to consciousness as meaningful phenomenal experience.' The Real, then, 'is the reality whose influence produces, in collaboration with the human mind, the phenomenal world of our experience. ${ }^{36}$ This shows that, for Hick, the Real serves as the ground of our experience of the world in a similarly neutral, objective way as science argues that gravity is the ground of mass. But this neutral, objective observation about such a ground differs fundamentally from the committed way in which religious people experience God as the ground of their lives, which is precisely the point that Kant tries to make when he calls the idea of God a regulative idea of reason. In sum, Hick tries to combine an objective and a subjective approach, a theoretical and a practical one, a neutral and a committed one, but fails to notice the fundamental rift that separates these two domains of reality, as well as the fact that, in religious matters, the latter approach predominates.

What this practical, life-orienting approach to God concretely means becomes apparent when we make a short detour and further examine Ratzinger's puzzling exhortation to secular people to 'live as if God exists. He is obviously intrigued by the universality that Kant's regulative use of the idea of God implies, and applies it to the problem of a moral and political normativity in a radically pluralist world. Contemporary democratic society is confronted with the problem that, because every

${ }^{36}$ John Hick, An Interpretation of Religion, p. 243. 
kind of normativity should be the result of political consensus only, it runs the risk that a coincidental majority can impose its views, which eventually may prove to be unjust. In Ratzinger's view, this problem is symptomatic for a pluralistic society that by definition lacks a common moral point of orientation that transcends the here and now. ${ }^{37}$ The very reality of societal pluralism shows that the idea of such a moral and political normativity is not actually 'available' as an object of moral knowing, but it is nevertheless 'subjectively' needed for the sake of justice. In Ratzinger's eyes, Kant's proposal to approach God as a universal regulative idea in order to orientate the plurality of human thinking towards an original idea of systematic and dynamic unity is very useful to offer a solution to this problem. Because of its transcendent character, the idea of a moral and political normativity is inevitably a regulative one, which means that it cannot be given objectively, but only problematically. It is the asymptotic point, to which the existing moral plurality endlessly approximates without ever being able to reach it. But at the same time it is far more than a neutral hypothesis that may be introduced in order to solve a theoretical problem. Instead, it is indispensible for all people, religious and secular, since it fulfils their (subjective) need to orient their lives towards such a unifying point, so that it can serve as a common ground in times of radical pluralism. Hans Joas has made a suggestion in this respect that deserves to be further examined: he proposes the idea of human dignity as a universal principle that orients the existing plurality of moral and political norms and thus serves as a guiding principle for a just consensus building. ${ }^{38}$ When we apply this to Ratzinger's suggestion of living as if God exists, it means that all people, religious and secular, should be prepared to let their lives be oriented by such a normative principle. Precisely because it is not actually given as an object of (moral) knowledge, this principle is left open to diverse interpretations, religious and secular ones, and hence can serve as a common ground in times of radical pluralism.

Kant's account of the indispensable regulative function of the idea of God helps me to comment on another important aspect of critical

37 I have shown elsewhere that prominent secular political philosophers, such as Habermas and Rawls, also take this as a crucial problem for liberal societies. See: Peter Jonkers, 'A Purifying Force for Reason? Pope Benedict on the Role of Christianity in Advanced Modernity', pp. 92-96.

${ }^{38}$ Hans Joas, Die Sakralität der menschlichen Person: Eine neue Genealogie der Menschenrechte (Berlin: Suhrkamp, 2011), p. 303. 
theological realism, which also plays a predominant role in Hick's philosophy of religion. According to Hick, our cultural situatedness implies that all the world religions are different or even conflicting renderings of the same ultimate reality, while none of them can legitimately claim to be the one and only true rendering of this reality. ${ }^{39}$ He uses the Kantian distinction between the phenomenal order of religious diversity and the noumenal order of the one ultimate reality to underpin his view philosophically. By accepting the reality of religious pluralism and showing that all world-religions are renderings of the Real, Hick is able to give a solution to the intricate problem of religious exclusivism. However, in my opinion, Kant's distinction has another important consequence for religious pluralism, which seems to have escaped Hick's attention. In Kant's view, the noumenal, in particular the idea of the Real an sich, not only fundamentally differs from the phenomenal variety of religions, but also serves as a regulative idea for phenomenal reality. Again, Hick accepts the first insight, but refuses the second. He considers the Real an sich as so fundamentally different from its appearance in mundane reality that the former cannot be qualified in any way by human thinking. The Real an sich 'cannot be said to be one or many, person or thing, substance or process, good or evil, purposive or non-purposive. ${ }^{40}$ We only can make certain purely formal statements about the Real in itself, such as Anselm's definition of God as that than which no greater can be conceived. ${ }^{41}$

The above not only implies that we are unable to qualify the Real an sich in any substantial way, but also, reversely, that the Real cannot serve as a reference point to distinguish between authentic and inauthentic manifestations of it. On the other hand, Hick also recognizes 'that not all religious persons, practices and beliefs are of equal value, ${ }^{42}$ and develops criteria to make such distinctions on rational grounds. He thereby comes to the conclusion that 'religious traditions and their various components - beliefs, modes of experience, scriptures, rituals, disciplines, ethics and lifestyles, social rules and organizations - have greater or less value according as they promote or hinder the salvific transformation. ${ }^{43}$ But these criteria are only internal, i.e. they only

\footnotetext{
${ }^{39}$ John Hick, An Interpretation of Religion, p. 243.

${ }^{40}$ John Hick, An Interpretation of Religion, p. 246.

${ }^{41}$ John Hick, An Interpretation of Religion, p. 246.

${ }^{42}$ John Hick, An Interpretation of Religion, p. 299.

${ }^{43}$ John Hick, An Interpretation of Religion, p. 300.
} 
concern the phenomenal variety of religions, but have no relation to the Real an sich, which is radically external with regard to the phenomenal plurality of religions. In my view, Hick's position is quite problematic in this respect, because one cannot, on the basis of purely internal criteria, determine why a religion should be salvific at all, or why the spiritual and moral fruits of one religious tradition are more salvific than those over another one. On a more fundamental level, Hick's position yields to non-realism: if the Real an sich does not qualify the phenomenal (variety of religions) in any way, one can legitimately ask whether we could not as well drop it altogether.

By contrast, Kant's suggestion about the regulative function of the noumenal with regard to the phenomenal order offers a far better solution to this problem. When applied to philosophy of religion, the regulative idea of reason does not provide an unequivocal positive criterion to determine which religion is the one and only true one, but it does offer a crucial negative criterion to criticize (aspects of) religions that run counter to this idea, because they fail to include certain crucial aspects of salvation. Moreover, because of its noumenal character, this regulative idea is external with regard to the phenomenal variety of religions, and hence is able to offer a stronger kind of normativity than the internal criteria that are developed by the various religions. In my view, Kant's suggestion does more justice to the essential critical dimension of philosophy of religion with regard to all the existing religions than Hick's position. ${ }^{44}$

\subsection{Is the idea of God nothing but a heuristic fiction?}

However, the crucial question that has not yet been answered is how the indispensible regulative employment of the idea of God relates to theological realism's most fundamental claim, namely God's existence as an independent reality. Let us first again explore Kant's position on

\footnotetext{
${ }^{44}$ Kant points out the critical function of transcendental theology, to which theological realism belongs, quite clearly. Foreshadowing the affirmation of God's existence as a postulate of practical reason he states: 'For if, [...] perhaps on practical grounds, the presupposition of a supreme and self-sufficient being, as the highest intelligence, established its validity beyond all question, it would be of the greatest importance [...] to free it from whatever [...] is out of keeping with the supreme reality, and at the same time to dispose of all counter-assertions, whether atheistic, deistic, or anthropomorphic.' See Immanuel Kant, 'Kritik der reinen Vernunft', p. B 668.
} 
this problem a bit further. The excellent and indispensible regulative employment of the idea of reason does not mean that this idea would be more for theoretical reason than a focus imaginarius, or a heuristic fiction. ${ }^{45}$ This means that it has no objective reality and thus cannot become an object of scientific knowledge. In order to clarify things somewhat Kant compares the idea of reason with the image in a mirror of an object behind us. Because what we see in the mirror is only a reduced image of the 'real' object, it lacks essential aspects of objectivity (it has no depth, cannot be touched, heard or smelled). Hence, this image is not an object of our knowledge in the strict sense, so that its ontological and epistemological status can never be more than that of a heuristic fiction. It is obvious that, in this theoretical respect, calling God a heuristic fiction runs counter to theological realism's affirmation of God's objective existence. But Kant also states that this image is indispensible in order find out (the Greek word heuristein literally means to find out) what is happening behind our back; in other words, although this image is a heuristic fiction on a theoretical level, it is nevertheless indispensible in a practical sense, namely for our orientation, e.g. when we drive a car. Hence, counter to theological realism's affirmation of the objective reality of God Kant concludes that the best theoretical philosophy can make of it is 'that the things of the world must be viewed as if they received their existence from a highest intelligence. ${ }^{46}$ The combination of 'must' and 'as if' shows that God is an objectively problematic idea, while assuming his existence is subjectively indispensible.

The above shows that Kant passes a negative judgment on any philosophical affirmation of God's existence as an objective, independent reality, but also that he leaves room for another approach, which he qualifies as a subjective or practical one. He describes the difference between these two approaches as follows: '[T]heoretical knowledge may be defined as knowledge of what is, practical knowledge as the representation of what ought to be. ${ }^{34}$ Practical knowledge is not limited to a set of moral principles, but comprises all conditions that are necessary for humans to commit themselves to acting morally. This includes God as a postulate of practical reason. Postulating God on practical grounds clearly differs from taking him as a theoretical hypothesis: '[T] he

${ }^{45}$ Immanuel Kant, 'Kritik der reinen Vernunft', pp. B 672f.; see also p. B 699.

${ }^{46}$ Immanuel Kant, 'Kritik der reinen Vernunft', pp. B 698f.; see also p. B 714.

${ }^{47}$ Immanuel Kant, 'Kritik der reinen Vernunft', p. B 661. 
moral laws do not merely presuppose the existence of a supreme being [as an optional and contingent hypothesis], but also [...] justify us in postulating it, though, indeed, only from a practical point of view. ${ }^{3}{ }^{48}$ This means practical reason does not provide us with knowledge of God an sich, apart from our conceptual structures, so that we have no idea at all of God's reality, nor how to represent or to depict him. But although God is no object of theoretical reason, He is the ultimate object of our moral will as (an element of) the highest good. In order to make this object possible, His existence has to be postulated by practical reason. The postulates 'do not enlarge speculative knowledge, but (through their connection to practical matters) they give an objective reality to the ideas of speculative reason. ${ }^{39}$

The above analysis makes clear that God is definitely more than a heuristic fiction. However, in order to serve as a relevant comment on theological realism this 'more' needs further qualification. First of all, stating that God's reality is a postulate of practical reason implies that the affirmation of His existence cannot result from theoretical considerations, such as the correspondence between our religious concepts and propositions and supernatural reality, or from an analogy between the natural and the supernatural..$^{50}$ As I argued in the second section of this paper, God fundamentally exceeds all worldly categories, so that every attempt to affirm his existence on the basis of such a correspondence or analogy inevitably leads to an imaginative projection, and, hence, from a religious perspective, to idolatry. Instead, I propose to think of God as a symbolic reality, which defines Him as a spiritual, rather than as a natural reality. More specifically, as the highest good God is the ultimate orientation point of our lives as moral beings, and hence is the highest, transcendent symbolic reality. This also relates God's existence to the domain of human culture, but without linking him exclusively to this or that specific (religious) culture, nor reducing him to a product

${ }^{48}$ Immanuel Kant, 'Kritik der reinen Vernunft', p. B 662.

${ }^{49}$ Immanuel Kant, 'Kritik der praktischen Vernunft', p. 264.

50 On this point I do not agree with Brunsveld's interpretation of Hick's position. Brunsveld links Hick's postulating of God's existence with a correspondence between the phenomenal and the noumenal. But Hick considers the Real an sich (the noumenal) as so fundamentally different from its appearance in mundane reality that the former cannot be qualified in any way by human thinking. This implies that there cannot be a correspondence between the noumenal and the phenomenal world. See Niek Brunsveld, The Many Faces of Religious Pluralism, p. 44. 
of it. Thinking of God as a symbolic reality somehow softens the rift between the phenomenal and the noumenal, not on a theoretical, but on a practical level. Furthermore, qualifying God's symbolic reality as the highest good offers a philosophical underpinning the essential salvific character of the Real, which Hick refuses to accept.

Finally, the affirmation of God as a symbolic reality, more specifically as the highest good, may be seen as an expression of reasonable faith. This faith is reasonable and not revealed, because it 'springs from pure reason (according to its theoretical as well as its practical use). ${ }^{51}$ In this respect, Kant makes an important distinction between opining, knowing, and believing, which sheds an important light on the epistemological aspect of theological realism. Holding something to be true rests, of course, on objective grounds (namely on the correspondence of a judgment with an object or state of affairs), but also requires a subjective element, which is called a conviction (if the judgment is valid for every reasonable being) or a persuasion (if it is a private opinion). As to the subjective aspect of the validity of a judgment, more specifically of a conviction, Kant distinguishes three levels: 'Opining, believing and knowing. Opining is such holding of a judgment as is consciously insufficient, not only objectively, but also subjectively. If our holding of the judgment be only subjectively sufficient, and is at the same time taken as being objectively insufficient, we have that what is termed believing. Lastly, when the holding of a thing to be true is sufficient both subjectively and objectively, it is knowledge. ${ }^{.52}$ As far as we are striving for the enlargement of our theoretical knowledge, we are not permitted to hold the judgment that God really exists to be true, because there is no object or state of affairs to which such a judgment corresponds; in other words, the judgment that God really exists, as theological realism claims, lacks the objective sufficiency that is needed for all theoretical knowledge. But from a practical point of view it very well makes sense to believe or have faith in the truth of a judgment that is insufficient to hold true from a theoretical point of view. This is especially the case when practical reason requires a point of orientation for our moral life, while lacking objective certainty about it. Hence, it makes perfect sense to have a reasonable faith (as opposed to a revealed one) in God, which allows us to hold the judgment that

${ }^{51}$ Immanuel Kant, 'Kritik der praktischen Vernunft', p. 257.

${ }^{52}$ Immanuel Kant, 'Kritik der reinen Vernunft', p. B 850. It has to be noted that the German word 'Glaube' can be translated both by 'belief' and 'faith'. 
God exists to be true on sufficient subjective grounds, although we are fully aware that we lack the objective sufficiency that would make this judgment to a certainty for theoretical knowledge.

\section{CONCLUSION}

With this paper I hope to have shown that theological realism's predominantly theoretical approach to God's reality is problematic, basically because it rests on the epistemological presupposition of being able to represent or depict the divine reality in a way that is similar to science. Instead, I suggest to approach God's reality from a practical perspective, as an indispensible regulative idea for our orientation in life. This does not reduce God to a heuristic fiction, but affirms his reality on a symbolic level, as a postulate of practical reason.

Acknowledgment. This paper was originally presented in Mainz, Germany, at a conference for the Analytic Theology Project, generously funded by the John Templeton Foundation. 